Lechosław Lameński*

\title{
Byłem uczniem, asystentem i współpracownikiem Profesora Jacka Woźniakowskiego
}

\author{
DOI: http://dx.doi.org/10.12775/LC.2018.007
}

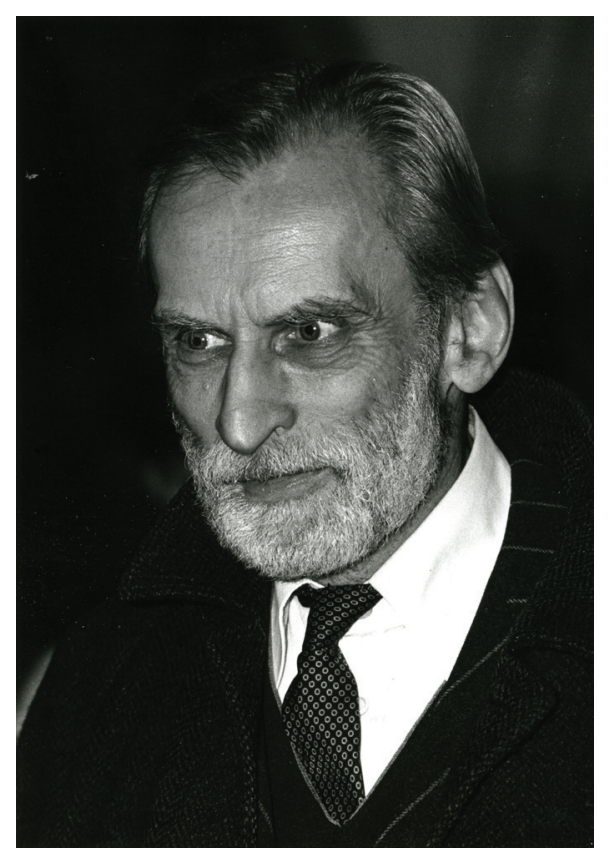

Profesor Jacek Woźniakowski.

Fotografia z prywatnego archiwum Lechosława Lameńskiego

Profesor, kierownik Katedry Historii Sztuki Nowoczesnej i Współczesnej Katolickiego Uniwersytetu Lubelskiego. Zajmuje się głównie sztuką polską od połowy XIX wieku do 1939 roku (zwłaszcza rzeźbą i architekturą).E-mail: lamenski@wp.pl. 
spomnienie o Profesorze Jacku Woźniakowskim rozpocznę od powtórzenia kilku faktów, które zawarłem w swoich wcześniejszych tekstach poświęconych Jego pamięci (opublikowanych na łamach „Przeglądu Uniwersyteckiego KUL” 6/2012 i „Biuletynu Historii Sztuki” 1/2014); faktów - w moim przekonaniu - kluczowych dla zarysowania portretu Profesora.

Pana Profesora poznałem w 1971 roku. Byłem wówczas studentem III roku historii sztuki. Pojawił się wraz ze swoim przyjacielem prof. Andrzejem Ryszkiewiczem (wybitnym znawcą malarstwa polskiego XIX wieku i kolekcjonerem) na pierwszym w dziejach ówczesnej Sekcji Historii Sztuki (dzisiaj Instytut Historii Sztuki) Katolickiego Uniwersytetu Lubelskiego seminarium $\mathrm{z}$ historii sztuki nowoczesnej. Wysoki, szczupły, ubrany trochę nonszalancko, choć z wyszukaną elegancją, w nieodłącznym pulowerku, z marynarką z naszytymi na rękawy na wysokości łokci owalnymi łatami, wręcz sparaliżował nas przenikliwym, niemalże hipnotyzującym wzrokiem. Mówił niewiele, ale za to bardzo precyzyjnie i dobitnie. Aury tajemniczości dodawała Mu również wyraźna blizna na policzku, pozostałość - jak się dowiedzieliśmy znacznie później - po ciężkiej ranie odniesionej podczas walk w kampanii wrześniowej, w której brał czynny udział jako podchorąży 8 Pułku Ułanów. Z czasem bliznę zastąpiła krótka, elegancka broda, która stała się znakiem rozpoznawczym Pana Profesora w latach następnych.

Od starszych kolegów dowiedzieliśmy się, że Pan Profesor, związany z naszą uczelnią od 1952 roku, będzie miał z nami zajęcia $\mathrm{z}$ historii sztuki nowoczesnej powszechnej i polskiej (wykłady kursowe, monograficzne i seminarium magisterskie). Po wysłuchaniu pierwszego z wykładów wiedzieliśmy już, że będziemy nań chodzić wszyscy. Profesor urzekł nas bowiem przede wszystkim swoją niebywałą erudycją i rozległą wiedzą, ale także umiejętnością trafiania do słuchacza. Wszystko, co mówił, było starannie zakomponowane, podane nienaganną polszczyzną ( $\mathrm{z}$ wykształcenia był bowiem filologiem polskim i filozofem, uczniem prof. Stanisława Pigonia, pod którego kierunkiem napisał na Uniwersytecie Jagiellońskim magisterium poświęcone Stanisławowi Witkiewiczowi), z obowiązkowymi interwałami i anegdotami, gdy wymagała tego sytuacja. Starał się nam przekazać nie tylko określoną sumę wiedzy na wybrane tematy, ale także nauczyć nas patrzeć i rozumieć trudne oraz złożone problemy sztuki nowoczesnej i współczesnej. Wiele czasu spędzał w Zakopanem w słynnej willi „Pod Jedlami” zaprojektowanej przez przywołanego już Witkiewicza dla jego dziadka, Jana Gwalberta Pawlikowskiego - ekonomisty, publicysty i polityka, historyka literatury, a zarazem taternika, jednego z pionierów ochrony przyrody tatrzańskiej. Nie dziwi więc, że potrafił również zarazić - przynajmniej niektórych $\mathrm{z}$ nas - miłością do gór, które stały się przedmiotem Jego wieloletnich, sprawiających $\mathrm{Mu}$ największą przyjemność badań i tematem cieszącego się ogromną popularnością wykładu monograficznego. Wykładu, na który przychodzili niemal wszyscy studenci naszej Sekcji, uczęszczało też nań bardzo dużo studentów innych kierunków, bez względu na zainteresowania, bo tak naprawdę chodziło się na Jacka Woźniakowskiego. Tyle tytułem wstępu. Pora przejść do wspomnień, które towarzyszyły mi przez długie lata. Teraz nadarzyła się okazja, by podzielić się nimi i przelać je na papier.

Przez kolejne dwa lata moich studiów przygotowywałem pracę magisterską pod kierunkiem wspomnianego wcześniej prof. Andrzeja Ryszkiewicza, ale Profesora Jacka 
Woźniakowskiego widywałem regularnie, ponieważ seminarium prowadzili obaj panowie do spółki, dojeżdżając co dwa tygodnie do Lublina z Warszawy i Krakowa. Magistrantką Pana Profesora została natomiast koleżanka z roku, Ewa Wójtowicz, moja przyszła żona. Na koniec czwartego roku przyszło nam zdawać bardzo trudny egzamin ze sztuki nowoczesnej. Chyba wypadłem bardzo dobrze, na tyle dobrze, że Pan Profesor zaproponował mi stypendium zakładowe. W jego ramach rozpocząłem porządkowanie księgozbioru Katedry, pisałem fiszki katalogowe, pełniłem dyżury, a jak trzeba było, parzyłem również dla Niego herbatę. To chyba wówczas Pan Profesor po raz pierwszy zwrócił na mnie uwagę, pytając o moje plany na przyszłość, po ukończeniu studiów. Nie miałem ochoty wracać do rodzinnej Bydgoszczy, ani tym bardziej jechać do Tarnowa, skąd pochodziła Ewa. W czerwcu 1973 roku - jeszcze przed egzaminami magisterskimi - pobraliśmy się, z zamiarem podjęcia pracy na miejscu, w Lublinie. W tym momencie Profesor Jacek Woźniakowski zaproponował nam, aby jedno z nas zostało jego asystentem. Co prawda - jak powiedział - zna lepiej Ewę (w końcu napisała pod jego kierunkiem świetną pracę magisterską) i dlatego jest mu bliższa, ale zna życie i wie, że czasami kobiety po wyjściu za mąż rodzą dzieci, co na pewien czas wyłącza je z pracy zawodowej. W tej sytuacji uznał, że lepiej będzie, jeżeli asystentem zostanę ja. Tak też się stało. W efekcie, od października 1974 aż do przejścia przez Pana Profesora na emeryturę w 1990 roku, byłem Jego asystentem, a z czasem także najbliższym współpracownikiem.

Niemniej wielokrotnie zastanawiałem się, dlaczego - tak naprawdę - to właśnie mnie przypadła w udziale asystentura u Jego boku. W końcu kandydatów było - jak mi się wydawało - co najmniej kilku. Dlaczego Pan Profesor wybrał ostatecznie mnie, prostego chłopaka z Bydgoszczy, z masą kompleksów, niewyobrażającego sobie, że można zarabiać na życie mówieniem i pisaniem (miałem z tym wówczas spore problemy), trochę niesfornego, ale być może wykazującego predyspozycje do pracy dydaktyczno-naukowej (tak przynajmniej twierdzili obaj moi Profesorowie). Po latach najbliższa wydaje mi się bardzo prozaiczna koncepcja, że asystentem Pana Profesora zostałem tylko dlatego, że tak jak jego pierworodny syn, Henryk Woźniakowski, urodziłem się 22 czerwca 1949 roku, a więc dokładnie w pierwszą rocznicę Jego ślubu z Panią Mają z domu Plater-Zyberk.

Byłem klasycznym asystentem. Nosiłem za Panem Profesorem książki i slajdy na wykłady, uczestniczyłem we wszystkich Jego zajęciach, zajmowałem się stroną organizacyjną seminariów (zarówno magisterskiego, jak i doktorskiego), a co dwa tygodnie odbierałem Go również z dworca kolejowego, załatwiałem wreszcie wszystkie powierzone mi sprawy katedralne i sekcyjne. Pan Profesor odwdzięczał się życzliwością, poznawał mnie z ciekawymi ludźmi, przede wszystkim jednak dużo ze mną rozmawiał. Rozmowy te stopniowo poszerzały moje horyzonty i wiedzę o współczesnym świecie.

Pan Profesor Jacek Woźniakowski, prawdziwy Europejczyk, ogromny erudyta (znał biegle co najmniej pięć języków), a zarazem żarliwy katolik, do szpiku kości uczciwy, stający zawsze po stronie słabszych i ciemiężonych, uwielbiał wszelkiego rodzaju spotkania towarzyskie i dyskusje. Czuł się wówczas jak ryba w wodzie, mógł bowiem z pasją rozmawiać na interesujące Go tematy - a było ich niewyobrażalnie dużo - całymi godzinami. Nic więc dziwnego, że niemalże za każdym przyjazdem Pana Profesora do Lublina staraliśmy się zorganizować tzw. kolacyjki, w których uczestniczyliśmy głównie my, zafascynowani Jego osobowością, młodzi pracownicy ówczesnej Sekcji Historii Sztuki, a także zaproszeni goście. Najczęściej spotykaliśmy się najpierw w niewielkim mieszkaniu lubelskim naszej koleżanki, 
pani Bożeny Iwaszkiewicz-Wronkowskiej, a następnie w jej obszernym i niezwykle gościnnym domu w Niedrzwicy Kościelnej w pobliżu Lublina. Profesor uwielbiał Bożenkę, a to, że w latach siedemdziesiątych i osiemdziesiątych XX wieku była związana z opozycją, zwłaszcza z kręgiem ludzi współtworzących wydawane poza cenzurą pismo młodych katolików „Spotkania”, tylko sprzyjało pogłębianiu obustronnej sympatii. „Kolacyjki” rozpoczynały się z reguły około godziny 19.00 i ciągnęły się do późna w nocy. Któregoś razu, po obronie doktoratu mego kolegi z Katedry, Piotra Rudzińskiego, Pan Profesor przyszedł na spotkanie wyraźnie zmęczony. Zarówno w Krakowie, jak i w Lublinie prowadził bowiem bardzo intensywny i pracowity tryb życia. Nie oszczędzał się, załatwiał całą masę spraw, zarówno tych o charakterze lokalnym, jak i - w gruncie rzeczy - państwowym, a przecież nigdy nie był tytanem zdrowia. Po pewnym czasie, już po zjedzeniu wyjątkowo smacznej kolacji i po pierwszej wymianie myśli, Pan Profesor zasiadł w wygodnym fotelu i... zasnął. Ponieważ zdarzyło się to pierwszy raz, nie wiedzieliśmy, jak się zachować, niemniej nikt nie myślał o zakończeniu spotkania. Postanowiliśmy w ciszy i skupieniu poczekać w pokoju obok, co nastąpi dalej. Stan niepewności trwał około dwóch godzin, kiedy to Pan Profesor obudził się i - jak gdyby nic - kontynuował dyskusję o tym, jak powinien wyglądać nasz uniwersytet w przyszłości, gdy to my będziemy na jego miejscu. Po kilku kolejnych godzinach wszyscy padaliśmy ze zmęczenia, tylko Pan Profesor, świeży i wypoczęty, w dalszym ciągu miał ochotę na wymianę myśli i poglądów, nie za bardzo mogąc zrozumieć, dlaczego młode pokolenie współczesnych Polaków jest tak mało wytrzymałe. Ostatecznie spotkanie zakończyło się we wczesnych godzinach porannych.

Pan Profesor Jacek Woźniakowski był bez wątpienia człowiekiem bardzo wymagającym wobec siebie i swoich współpracowników. Miał zresztą w tej materii duże doświadczenie, zarówno w latach, gdy był członkiem pierwszego kolegium redakcyjnego „Tygodnika Powszechnego", jak i gdy w 1959 roku założył Wydawnictwo Znak i był jego wieloletnim - do 1990 roku - dyrektorem. Ogromna odpowiedzialność i pracowitość nie zawsze szły jednak w parze z punktualnością. Nadmiar obowiązków powodował, że zdarzało $\mathrm{Mu}$ się spóźniać także na wykłady. Z reguły czekano na Pana Profesora aż do skutku, ale któregoś roku - chyba w pierwszym roku mojej pracy na KUL-u - studenci po czterdziestu minutach bezproduktywnego oczekiwania zdenerwowali się Jego nieobecnością i rozeszli się. W tym momencie Pan Profesor pojawił się w drzwiach sali wykładowej. Puste krzesła zdziwiły go niezmiernie, jednak nie skomentował tego faktu. Ale gdy pod koniec semestru doszło do zaliczeń i wpisów w indeksach, niespodziewanie wyjechał z Lublina o jeden dzień wcześniej, zabierając ze sobą - nie pierwszy zresztą raz, przez roztargnienie - klucz do pokoju gościnnego w Konwikcie, gdzie z reguły nocował. Studenci pozostali z niepodpisanymi indeksami. Wszystkim groziła sesja warunkowa, a być może nawet tzw. dwóje dziekańskie. Ostatecznie, po burzliwych negocjacjach - w których brałem aktywny udział - Pan Profesor uznał, że jednak podpisze wszystkim wykład, o ile ktoś przywiezie Mu do Krakowa indeksy. Ktoś, czyli ja, Jego asystent. Zapakowałem kilkadziesiąt indeksów do worka, wsiadłem wieczorem do pociągu i pojechałem. Mimo trudów podróży była to jedna z moich najprzyjemniejszych wizyt w historycznym grodzie Kraka... Nie tylko dlatego, że chyba właśnie wówczas poznałem całą czwórkę dzieci Profesora: mego „brata” bliźniaka Henryka, córki Różę i Annę oraz najmłodszego w tym gronie Jana, ale być może dlatego, że Pani Maja potraktowała mnie jak swego trzeciego syna, nakarmiła i otoczyła prawdziwie matczyną opieką. Od tego momentu bywałem wielokrotnie i w miarę regularnie w gościnnych 
progach mieszkania Państwa Woźniakowskich (najpierw przy ul. Wyspiańskiego, następnie przy ul. Pijarskiej), a Pani Maja zawsze okazywała żywe zainteresowanie moimi sprawami, zarówno tymi dobrymi, jak i złymi, z czasem także tym, co dzieje się z moimi córkami, chętnie służąc radą i pomocą w rozwiązywaniu wielu problemów rodzinnych.

Kolejne lata mojej asystentury przebiegały w miarę spokojnie, chociaż bywało, że dochodziło do całego szeregu momentów kryzysowych, wywołanych z jednej strony moim niewłaściwym zachowaniem (naprawdę bywałem czasami wyjątkowo nieodpowiedzialnym młodym człowiekiem), a z drugiej - moimi licznymi kompleksami, zwłaszcza niewiarą we własne możliwości. Pod koniec lat siedemdziesiątych XX wieku, jeszcze przed zrobieniem doktoratu, pełen wątpliwości, czy w ogóle potrafię go napisać, a następnie obronić, zdesperowany do granic wytrzymałości, postanowiłem ostatecznie złożyć na ręce Pana Profesora moją rezygnację z pracy w KUL. Ten spojrzał mi głęboko w oczy i zapytał: „Lechu (byliśmy jednostronnie po imieniu), czy masz do mnie rzeczywiście ważną sprawę?". Gdy potwierdziłem, uznał, że w tej sytuacji należy porozmawiać spokojnie, ale nie na uniwersytecie. Poszliśmy więc do restauracji Unia w pobliskim Hotelu Orbis. Pan Profesor zamówił u kelnera dwie setki wódki i po śledziku. Najpierw wypiliśmy, a następnie - na Jego prośbę - „wyspowiadałem” się Mu ze wszystkich meczących mnie wątpliwości i lęków, tak jakbym to robił przed własnym ojcem. Gdy wychodziliśmy z restauracji, byłem już pewny swojej przyszłości.

Kilka lat później, spełniając oczekiwania Pana Profesora, obroniłem doktorat poświęcony życiu i twórczości Tadeusza Stryjeńskiego, najwybitniejszego polskiego architekta ze środowiska krakowskiego, czynnego twórczo od lat siedemdziesiątych XIX wieku po lata trzydzieste XX stulecia. Już wówczas Pan Profesor ufał mi tak dalece, że przyjął rozprawę po przeczytaniu zaledwie jednego z jej rozdziałów. Załatwił mi także druk książki w Wydawnictwie Literackim. Ale mogła ona mieć „tylko” czterysta stron, podczas gdy ja napisałem ich aż osiemset (pięćset stron tekstu oraz trzysta stron przypisów i katalogu). Na moje pełne przerażenia pytanie, jak skrócić rozprawę, Pan Profesor z charakterystyczną dla Niego swadą, wertując powoli strona po stronie, odpowiedział: „Wyrzuć co drugą kartkę". Wówczas uważałem to za pomysł całkowicie chybiony, z mojej perspektywy - nie do zaakceptowania, chociaż dzisiaj (a więc po upływie trzydziestu pięciu już lat) wiem, że to jednak Pan Profesor mial, jak zawsze zresztą, rację.

Potem było już tylko lepiej. Niestety, w 1990 roku nieubłagany upływ czasu zadecydował o przejściu Pana Profesora na zasłużoną emeryturę. Mimo to nasze kontakty trwały nadal. Bywałem często w Krakowie ze względu na moje zainteresowania naukowe, więc okazji do kolejnych spotkań było bardzo dużo. Także w 1990 roku, po krótkiej i ciężkiej chorobie, zmarła moja żona. Akurat w tym właśnie czasie Pan Profesor, przez rok, pełnił funkcję Prezydenta Miasta Krakowa. Mimo natłoku obowiązków przyjechał na pogrzeb do Tarnowa, czym sprawił radość nie tylko mnie, ale zwłaszcza zrozpaczonym rodzicom Ewy.

W latach następnych moje relacje z Profesorem Jackiem Woźniakowskim nie ulegały zmianie, spotykaliśmy się stosunkowo często i w miarę regularnie. Gdy w 1992 roku wyjeżdżałem z córkami na wakacje do Rzymu (notabene w mieście nad Tybrem pojawiłem się po raz pierwszy już w 1976 roku dzięki stypendium otrzymanym za pośrednictwem Pana Profesora), nie tylko poinformował mnie, z kim i gdzie powinienem się spotkać (otrzymałem wspaniałą listę nazwisk wraz z adresami), ale dał mi także w prezencie kilka tysięcy lirów na pierwsze wydatki. 
W 2006 roku postanowieniem Prezydenta RP Lecha Kaczyńskiego Pan Profesor został odznaczony Krzyżem Komandorskim Orderu Odrodzenia Polski „za wybitne zasługi dla rozwoju polskiej demokracji, za działalność na rzecz dialogu i dobra wspólnego”. Niestety, wkrótce potem stan zdrowia Pana Profesora gwałtownie się pogorszyl, doszło do wylewu, a w konsekwencji do częściowego paraliżu, pojawiły się również problemy z wymową, co chyba najbardziej Go irytowało. Pan Profesor przeprowadził się wraz z żoną do Warszawy. Państwo Woźniakowscy zamieszkali w mieszkaniu córki, Róży Thun. Kłopoty z chodzeniem spowodowały, że Pan Profesor, nie mogąc bywać tam, gdzie by tego chciał, był spragniony towarzystwa. Rozumiejąc to, a także spełniając prośbę Jego Małżonki, starałem się regularnie pojawiać w Warszawie, za każdym razem w towarzystwie kogoś innego, znanego Panu Profesorowi, najczęściej z lat pracy w KUL. Sprawy związane z uczelnią, zwłaszcza jednak dalsze losy Jego uczniów, były ciągle dla Niego ważne. Tak długo, jak starczyło $\mathrm{Mu}$ sił, wypytywał nas o nasze kariery, sprawy zawodowe i prywatne, doradzal, przestrzegał i pouczał. Żywo reagował na wszystkie kwestie polityczne związane z naszą codzienną rzeczywistością, cieszyły Go nasze sukcesy, martwiły porażki. Był z nas dumny.

Ostatni raz byłem w Warszawie u Pana Profesora chyba w połowie listopada 2012 roku, a więc zaledwie dwa tygodnie przed Jego śmiercią. Wszedłem z Panią Mają do pokoju, w którym siedział - tradycyjnie od pewnego czasu - w wygodnym fotelu, z nogami okrytymi kocem, nieruchomy, z zamkniętymi oczami, niereagujący na dźwięk głosu ani na dotyk dłoni, śmiertelnie wychudzony, w gruncie rzeczy nieobecny. Usiedliśmy po obu strona fotela, chwytając go za dłonie. Pani Maja powiedziała bowiem, że na pewno Pan Profesor tak by chciał i z całą pewnością poczuje nasze ciepło. Przez kilkadziesiąt minut rozmawialiśmy o KUL-u i o znajomych z Lublina, o mnie i o mojej rodzinie. Na koniec pogłaskałem lewą dłoń Pana Profesora. Tak samo jak On jestem bowiem mańkutem. Po chwili, wzruszony, wyszedłem. Kilkanaście dni później Pani Maja zatelefonowała, informując mnie o odejściu Pana Profesora.

Dzisiaj - sześć lat od Jego pogrzebu - co tydzień przed rozpoczęciem wykładu kursowego ze sztuki nowoczesnej polskiej patrzę na piękne zdjęcie Pana Profesora wykonane w latach siedemdziesiątych XX wieku, na kolejne zdjęcie Pana Profesora z żoną Mają na tle Tatr, wykonane z okazji sześćdziesiątej rocznicy Ich ślubu oraz na karykaturę Pana Profesora jako Prezydenta Miasta Krakowa, leżące na moim biurku w założonej przez Niego Katedrze Historii Sztuki Nowoczesnej i Współczesnej. Katedrze, którą kieruję już jako profesor od jesieni 1998 roku. Przez cały czas pamiętam jednocześnie o tym, że byłem nie tylko Jego uczniem, pierwszym doktorem i pierwszym asystentem, ale również to, że jestem duchowym i formalnym kontynuatorem koncepcji i idei, o których realizację Pan Profesor Jacek Woźniakowski walczył tak konsekwentnie przez wiele lat, począwszy od pewnego słonecznego dnia w 1952 roku, gdy pojawił się w gościnnych progach Katolickiego Uniwersytetu Lubelskiego. 